\title{
Presiding Ora Coastal Ecotourism in Maluku, Indonesia
}

\author{
Hengky, S. H. \\ Universitas Bina Darma, Prasetiya Mandiri, SHINE Institute \\ Email: hengky_halim@yahoo.com.au
}

Received: August 13, 2017 Accepted: August 23, 2017 Published: September 9, 2017

doi:10.5296/bms.v8i2.11827ＵRL: https://doi.org/10.5296/bms.v8i2.11827

\begin{abstract}
Resolving issues of tourism development needed to be supporting and resolved with the help of local government. Currently, the problem of regional tourism development did not base on the development of environment and ecosystem. National economic development is neither regional nor local. Nevertheless, the role of community involvement in tourism activities is necessary. In addition, it needed to develop of transportation infrastructure related to regional activities. Coastal ecotourism has proven to be the largest foreign exchange contributor to a region or country. For that reason, applying this concept, it could improve coastal tourism performance. In the long term, this tourism sector can defeat the mining, oil and gas sectors. Furthermore, the Ministry of Tourism states that Indonesia's tourism potential is prospective. This one-year quantitative and qualitative study conducted on the coast of Ora, Maluku, Indonesia. Randomly data obtained and distributed over questionnaires among stakeholders. The data has tabulated by using content analysis. The results of this study indicate that three of the six sub-concept's attributes are the main priorities. The rest of the attributes show that there are some culinary, fishery, cultural and marine ism potentials. They can contribute economically to local communities and local governments.
\end{abstract}

Keywords: Coastal Ecotourism; Culinary; Fishing, Marine 


\section{Introduction}

Ora Beach is one of the popular tourist destination in the eastern region of Indonesia that have to visit by marine lovers. This beach is located on the island of Maluku. The richness of a coral and beach fished is a pure biodiversity that could be enjoying only from the top of the cottage or villa where to stay. The beach with white sand is also a comfortable place to pamper yourself.

There do not many foreign and local tourists so this beach as a private zone. Indonesia's tourism potential is tremendous and growing. Moreover, Assistant of Business and Government Business Market Segment of Ministry of Tourism stated that tourism had predicted to be Indonesia's largest foreign exchange contributor to beat the mines, oil and gas in 2020. Ministry of Tourism stated that the potential of Indonesian tourism is extraordinarily powerful and growing. In 2020, tourism has predicted to be Indonesia's largest foreign exchange contributor to beat mining, oil, and gas. In 2020, the tourism sector is the largest foreign exchange contributor to Indonesia (Fay, 2017).

Indonesia's Tourism predicted has many competitive and comparative advantages. The sector is also contributing up to 10 percent of the nation's gross domestic product (GDP), which is the highest in ASEAN, with growth above the industry's average GDP. It spent a million US dollar to 170 percent GDP, the highest for the industrial sector in the country. Over the past five years, employment in the tourism sector has grown by 30 percent. There are at least 9.8 million or 8.4 percent of the employment generated by tourism, with the creator of the cheapest jobs being 5,000 US dollars per job. In terms of foreign exchange, tourism also contributed to the fourth national foreign exchange of 9.3 percent, with the highest foreign exchange earnings growth of 13 percent and marketing costs only two percent of the projected foreign exchange. The tourism industry had projected to be Indonesia's largest foreign exchange earner, at 24 billion US dollars in 2019, outpacing oil and gas, coal and palm oil sectors (MC, 2017).

\subsection{Introduce the Problem}

The development of tourism activities had focused only on the development of physical aspects only, as it only develops because of its natural potential. Currently in the development of tourism's activities have not seen efforts in creating tourism objects developed from cultural potential. In addition, the implementation of tourism activities has not fully felt by the surrounding community as same as investors. There are still many people that in the tourist area. They are still not participating have the benefits resulting from tourism activities.

Some of the main issues that faced is the arrangement commonly of tourist areas were being seen less by following the technical rules of spatial arrangement. This is apparent to the utilization of areas that have a slope is not feasible to be developed but still built into tourism objects. The construction of such accommodation facilities may cause a negative impact on tourism efforts. The limited of supporting facilities - infrastructure is also one of issues that 
need special attention. Support facilities and infrastructure is an important factor for the sustainability of tourism activities, such as the provision of access, accommodation, tourist transportation, and other supporting facilities. However, there is still a lot of neglected potential for agriculture, fisheries, plantations, which can be to develop into a creative product that can also support the development of tourism in this area in an integrated manner.

\subsection{Explore Importance of the Problem}

Based on the problems, it indicates that tourism development needs to support by local government. Tourism development problem of the region with the approach did not base on environmentally and ecosystem development yet. Moreover, linkages of the function of tourism activities with other sectors needed. Besides, it lacks of linking to national, regional and local economic development. Nevertheless, it needs a role of the community involvement in upstream tourism activities. However, it needs utilization of regional development plans on the country that related to the direction of the function of protection and cultivation. Atleast, it needs the development of intermodal integrated transportation infrastructure and linked to regional activities. (Chris 2015).

The concept of ecotourism has many benefits, especially for economic development in remote areas. Ecotourism can help support the livelihoods and diversification of coastal communities in the region. In addition, it has very low market entry barriers (Das and Chatterjee, 2015; Riasi and Pourmiri, 2015). Among the different ecotourism subcategories, coastal ecotourism has high growth potential due to its unique characteristics (Riasi and Pourmiri, 2016). Therefore, this study aims to respond to the Minister of Tourism statement while solving the problem by way of prioritizing Ora coastal ecotourism (CE) in Maluku.

\subsection{Relevant Scholarship}

Coastal ecotourism activities are the activities of ecotourists in visiting natural beaches. Indirectly, they become lovers of coastal communities that became their main destination in travelling. Fishing is another activity and a hobby and recreation that liked by them. As time passes, demand for CE increased. Therefore, the preservation of the coastal environment needs to maintain well and enhance the competitiveness of CE in the future. Many things make the tourists enjoy the natural beach atmosphere. These factors determine the quality of this ecotourism that includes landscape viewing, water quality, coastal swamp protection, fisheries, and regional specialties (Buckley, 2009; Halim, 2011; Hengky, 2017a, 2017b; Honey, 2008).

Recently, ecotourism concept in the context of useful beach tourism to protect the coastal environment and the habitat and marine animal is vulnerable to arrest. The concept is reminiscent of the need for environmental conservation - biotas and the culture of coastal communities (Hengky, 2017a, 2017b). This concept also supports the conservation of coastal environment that directly improve economic contribution to the region through the coastal ecotourism program (Boley and Green, 2016; Halim, 2014). The beauty of the coastal 
scenery and business management which was visited by the ecotourists is maintaining coastal resources naturally and seeks to reduce the negative impacts on the environment (Attemene and Eguavoen, 2017; Fitzgerald and Stronza 2016; Hengky, 2017c, 2017d). To meet the needs they need to better understanding about the management of their tour of the activity along the coast and reduce the environmental impact on this activity. The planning and management of $\mathrm{CE}$ in this century requires good coordination between the regional government and the management of tourism industry, tour guide, tourists and natural resources (Ban and Ramsaran, 2016; Conway \& Cawley, 2016; Halim, 2014).

Ecotourism-Coastal is a recreational activity involving the participation in tourists. The ecotourism activities include travel, accommodation, and coastal resources' care for protecting negative environmental impacts. They travel through the beach and coastal environments and increasing their knowledge. They need to reduce the environmental impact on their activities. This concept has been applying by showing the relationship between economic-socio-ecology. The realization of the program had implemented in the form of cooperation between tourists, local people, local government, and tour guide. This information is very valuable to support programs that is engaged in ecotourism business (Chien, 2016; Halim 2011, 2014; Pace and Morgan, 2017).

In addition, the understanding of coastal communities on ecotourism continues to increase as they participate in socially-economic-ecointegrated eco-tourism development programs. Mass tourism and ecotourism complement each other's needs from the two tourist segments. Both types of tourism are complementary and meet the needs of visitors from different contexts of both approach to national and international tourism policy. CE activities help the tourism activities integration program. Both program created sustainable livelihoods of coastal communities (Halim 2011, 2014; Hengky, 2017a, 2017b, Krause and Weir, 2011).

Furthermore, ecotourists loved to visit natural beaches. They become a beach lover's community. This is their main purpose of traveling. Nowadays, fishing has become part of the recreation favored by them. Over time, the need for CE becomes a new trend in the world of tourism. Therefore, the conservation of coastal environment becomes an important thing in increasing the main competitiveness of CE in the future. Many things make the tourists enjoy the natural beach atmosphere and clean. These factors determine the quality of CE that includes water-quality landscapes, marine -biota protection, wetlands, and fisheries. Traditional approaches to the management of areas along coastlines generally increase the environmental carrying capacity of erosion and conservation of coastal areas naturally (Almeyda et al., 2010; Diamantis, 2000; Chien, 2016; Halim 2011, 2014; Kelkit et al., 2010; Krause and Weir, 2011).

Many community-based ecotourism projects have been successfully implementing with the help of the development community to integrate CE to support sustainable tourism development policies. The indicators of the skills of tourism developers are linking to the success of exploiting opportunities and reducing barriers in addressing the cultural issues of local communities. In addition, the limited capacity of transport and marketing enterprises is 
an obstacle to ecotourism development. Therefore, all policymakers need a mutual agreement on realizing their program (Cobbinah, 2015; Lloret and Riera, 2008; Picard, 2015; Sakata and Prideaux, 2013).

The potential for coastal areas very supported a regional development, both social - culture and environment. Presentation of the beauty of coral reefs - anglers have an appeal to CE. The attraction had reflected by the increasing tourist visits from time to time. However, fishing ecotourism is generally still not growing rapidly, so its managers are still low income. The development of coastal fish-based coastal settlements urgently needed. Various social cultural activities in the fishing area can increase the economic income of the community. Similarly, the development of trading activities, management and sales of marine products and culinary ecotourism can maintain socio-cultural, economic and environmental development in a sustainable manner (Hengky, 2017a, 2017b, 2017c; Pace and Morgan, 2017; Picard, 2015; Porter et al., 2015; Rusli et al., 2015).

As above discussion, this study of CE covered travel-accommodation and coastal resources' care. Besides, it covered cultural activities, preserved of socio-economics, infrastructure development, marine - biota protection, managed and sales culinary ecotourism (Chien, 2016; Hengky, 2017a, 2017b, 2017c, 2017d; Pace and Morgan, 2017; Picard, 2015; Porter et al., 2015).

\section{Method}

This qualitative and quantitative research (Bryman, 2006) had conducted over a year from November 2014 - November 2015 on the coast of Ora, Maluku, Indonesia (Figure 1). About 270 of 350 respondents have responded to a consistent questionnaire. The questionnaire had distributed randomly over the respondents. They consist of ecotourist, tour guide, tour operator, hotel staff, bus driver, fisheries worker, traditional food maker and seller, caretaker. Local residents, local government staff, tourist souvenirs, tourism associations, and related agencies.

This interview had done in a structured and qualitative way. Quantitative answers had quantified by likert's scale. The questionnaire results are tabulated using content analysis (Gottschalk, 2013, Henderson, 1991) based on the concept of CE. Results of data processing in the process by using triangulation technique. This is to guide the observational consequences by comparing the results of these interviews and secondary data (Marwick and Uniger, 1975). The mood and interests of the interviewer compensate and influence the outcome of the interview. Overall, content analysis results from CE. Therefore, the timeliness of interviews will determine the success of its success. The core of this content analysis includes data mining, placement of each consistent attribute, consistent frequency calculation, and debate and discussion of its performance (Pace and Morgan, 2017; Nuzula et al., 2017; Loperena, 2016; Krause and Weir, 2011; Nouri et al., 2008). The concept of CE covered travel-accommodation-coastal resources' care, cultural activities, preserved of socio-economics, Infrastructure development, marine - biota protection, managed and sales 
culinary ecotourism (Chien, 2016; Hengky, 2017a, 2017b, 2017c, 2017d; Pace and Morgan, 2017; Picard, 2015; Porter et al., 2015).

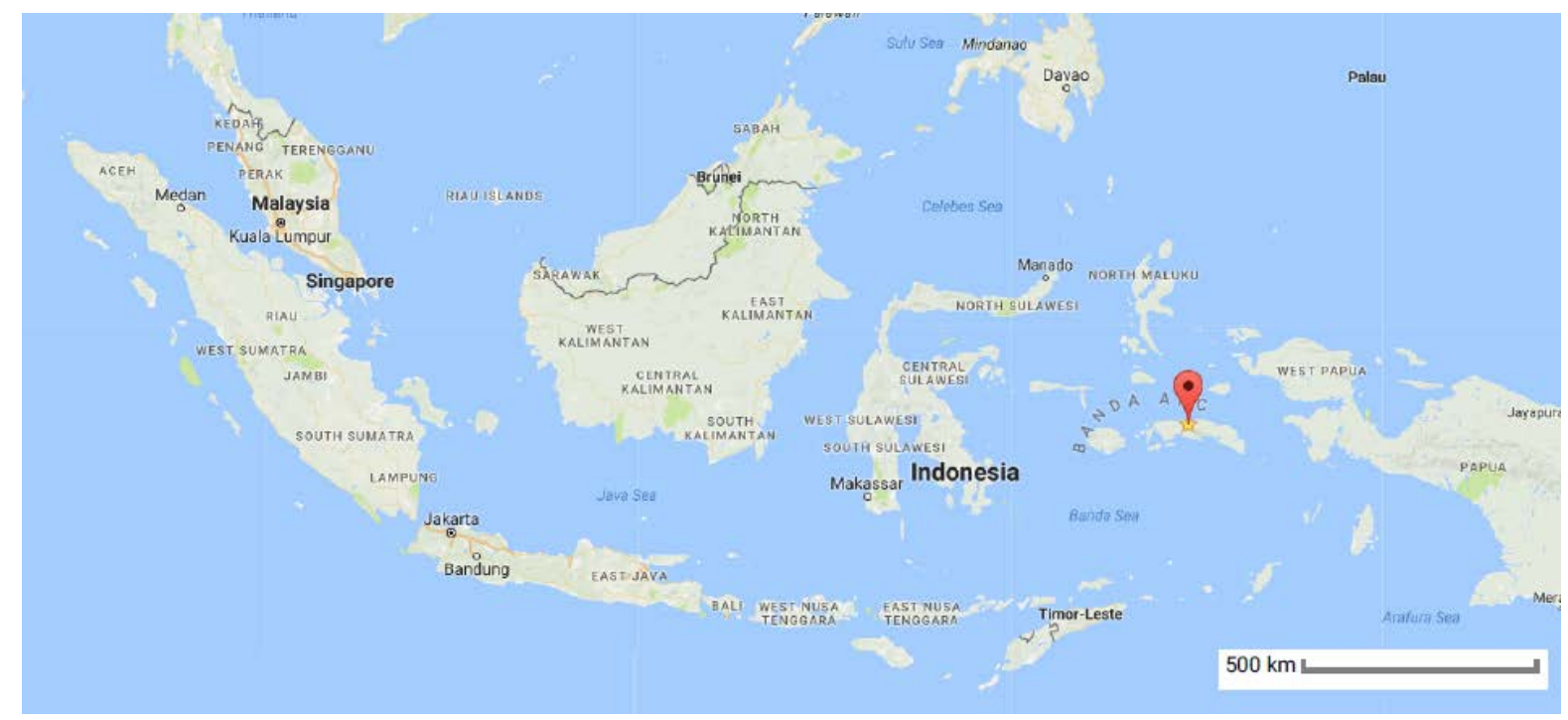

Figure 1.

\section{Results and Discussion}

The results of the content analysis tabulation (Table 1) indicate that the Ora coast performance approaches coastal ecotourism $(\mathrm{K}=0.5889)$. The advantages of the beach eco-tourism attribute of Ora became the ecotourists' decision to visit the area is travelling, accommodation and resources $(0.2075)$. Their decisions dominated by the performance of the scenic that well maintained and well preserved coastal. Preserved of socio-economics is the second attribute of the beach became their decision factors. It is clear that these eco-activities result in an economic contribution to the local community and a social interaction exists on them and ecotourism. The third advantage are marine - biota protection $(0.1635)$ which is the attraction of marine ecotourism such as diving. The fourth advantage are management and sales of culinary ecotourism (0.1572). The typical Ora coastal food is their attraction. They like to taste and enjoy the typical food of the region of its ingredients of a fresh sea fish-savory taste. These foods could only obtain around this beach. The fifth option are infrastructure development (0.1509). This is a reflection of the condition of the road to the location of this beach is still inadequate and access to the beach become a constraint on them. The sixth option are cultural activities (0.1384). Ecotourist very rarely got the art-cultural attractions of this coastal region that they are looking forward to the attraction. 
Table 1. Current performance of Ora coastal ecotourism

\begin{tabular}{lcc}
\hline Current performance of coastal ecotourism & Value & \% Freq \\
\hline Travel, accommodation, and coastal resources' care & 33 & 0,2075 \\
Cultural activities & 22 & 0,1384 \\
Preserved of socio-economics & 29 & 0,1824 \\
Infrastructure development & 24 & 0,1509 \\
Marine - biota protection & 26 & 0,1635 \\
Management and sales of culinary ecotourism & 25 & 0,1572 \\
\hline Kappa Coefficient $=\mathbf{K}_{\mathbf{1}}=\mathbf{0 , 5 8 8 9}$ & 0,5889 &
\end{tabular}

\subsection{Travelling, Accommodation and Resources Care}

This beach location is set in the hills of Manusela National Park. There stood graciously six thatch cottages. As ecotourists stared at a moment toward the sea, the coral reefs appeared colorful. This beach is located in Seram Island, Central Maluku. This beach namely the real paradise. The location hidden into a factor that adds to the attraction of the beach. Ecotourists did crave tranquility far from the urban hustle and bustle. Snorkling and diving is a mandatory agenda here. The resort did not provide the equipment. So that, they bring their own or rent in the nearest place. Endless beauty is suitable Ora. In fact, even at night they can still be amazed. Sitting on the dock and enjoying the glittering star flicker filled the sky (Riani, 2015).

An interesting experience of ecotourists is to live in a wooden house on the seawater. The dark night was full of surprises for them ranging from the sound of small waves of the presence of crabs into the room. Surrounding this beached, there are only seven wooden houses that each of them are size of ten square meters. The beach lies adjacent jungle and each of them all in-lined up neatly and within 20 meters. The house connected wooden bridge with a width of two fathoms between the first houses to the most end. At night, the atmosphere of this beach is quite different from the normal house. In front of the house is usually a green park (Surya, 2015a).

Currently, they can see a vast expanse of oceans with black. They easily see seawater a fish-coral reef under the house can easily from the sidelines of wooden floors on the veranda. With their tame fish, they seem forced to linger to see the panorama of nature under the sea is very fascinating. The lodge is not equipped with air conditioning. They open the front door that faces the sea that wanting to sleep to dissipate the heat. In order for the sea breeze can enter and stroked visitors that fell ill feeling sleepiness. What is clear, the swish of the waves became the most dominant night singing into an atmosphere that became their attraction. Every ten seconds, the water that arrives from the vast ocean to the mainland strikes the white sand of the beach and creates its own chaos. Not until like the waves, but far beyond the 
rushing water. For ecotourists that love nature, spend the night here full of beauties. The song of waves that faithfully accompanied could be like the music of nature without pauses and the vast ocean in front of the house to be the inspiration for the birth to a million poem. Various sea-night animals that continue to roam are a rhythm of friendship. Along the wooden bridge lit by 5 -watt lights, it makes a variety of sea animals huddles. Enjoying the night in the beach shacks is amazing. They deep sleep that rocked by the universe. Remind people not to damage the environment.

In addition to enjoying all the activities on the beach, tourists can also try trekking and see the beauty of forest in the land of Sawai. They are not just going through the forest. They can also visit an animal education and rehabilitation center. It is located in hamlets of Masihulan. There are breeding of Parrotfish (Cacatua moluccensis) and Parrot (Eclectus roratus) that seen by tourists. It also can continue the journey to a waterfall. The cave located in the middle of the forest. There is a cottage built by local residents that they can rest there. The trip seemed distant and exhausting. It paid when they arrived. They could enjoy the beauty of nature like the Heavenly Earth on the beach that provide a wonderful experience of each traveler (Febryna, 2014). They can also take a walk and cross the Salongan bar and watching local people made a sago and coconut fruit making. Upon arriving at bay estuaries of Sulaiman Bay, they can see the various kinds of birds that are there. Furthermore, surrounding Manusela National Park they can also find one of the other relaxing activities that can make in the morning. They can use motor boats and fishing boats around to see and enjoy the scenery and wandering around the Manusela National Park as the scenic backdrop of the resort.

\subsection{Preserved of Socio-Economics}

Strengthening socialization is very important especially starting from the grassroots to coastal communities with ecotourists. This can increase their knowledge in preserving the environment due to ecotourism activities. In addition, promotion of the program or concept is very necessary to inform the existence of CE. Furthermore, promotion program of tourism from the local government causing tourists to visit this beach is still very limited. Culture Tourism Office of Maluku Province stated that the promotion of tourism in the area is minimal budget. They admitted that with minimal of promotional costs and cannot do much with the promotion program. They make potluck, especially in every exhibition activity in a number of areas in the country and abroad. Last year they get an invitation to participate in promotional activities in Indonesia and abroad. It can be up to 50 times. Factually, they can participate only twice. It caused of limited budget constraints. Promoting of tourism is very important to do to introduce a number of tourist areas in the area. It attracted tourists to come to the beach. They compare the promotion of tourism in North Maluku province very well. It supported by a considerable promotional budget. It caused a number of tourist arrivals increased too (Patty, 2015;Fitriani, 2015).

\subsection{Marine - Biota Protection}


Coral reefs are one of the most important assets in a coastal and marine ecosystem. In addition to its enchanting beauty, coral reefs are also the home and playground of the fish. Two things become perfect for clear seawater. It is all on this beach. Unfortunately, there are sea animals around the beach that threaten the beauty of it. The name of the sea animals is Kaking. Sea animals shaped like a star and spiked at the top of this are always prey on coral reefs. With hundreds of feet and mouths at the bottom, Kaking most perches on the coral reefs. Apparently, this animal is not just hanging out and enjoying the beauty of the beach, but also suck the meat of coral reefs. It can kill coral reefs as big as baskets in less than a day.

Kaking that in scientific language crowns of thorns starfishes is also becoming the main enemy of divers. A poison at the tip of it spines would make a fever up to three days and three nights. The diver's body shivered and hurt all. Local youth did Kaking cleaning for the convenience of visitors to this beach and surrounding areas. They managed to lift more than 1,000 Kaking and buried them near water springs of Netherlands. This cooperation sponsored by resort executives, also because of the environmentally conscious society (Surya, 2015b).

The youths captured Kaking's life that walked like a snail and lifted with wood media then placed upside down on the mainland. It would be more effective as they directly buried. In some developed countries, the beautiful-looking animal killed by injecting certain substances into its body. However, this method considered too expensive to apply to this beach. The role of local government. They do not suggest to killing it at sea then the eggs directly spread and gave birth to thousands of other Kaking. They must come to preserve the environment by making Kaking program regularly.

Besides enjoying the beach scene of white sand and beautiful blue sea. One of the other activities that have are done by other is to dive and see the beauty of the underwater coast is so amazing. The tourists only need to dive into 2-3 meters. They have been able to see the beauty of various coral reefs. They greeted with small fish swimming around too. They should do snorkel in the deeper waters that do not damage the coral in the shallow coastal waters.

\subsection{Management and Sales of Culinary Ecotourism}

Around this beach, many traditional foods typical of the Maluku region, among others, porridge of sago yam, it served as an appetizer before eating. Furthermore, Papeda usually served as yellow sauce (as a vegetable). In addition, tourists enjoy Tagas-tagas in the form of dried vegetables. Furthermore, they can also enjoy Shasimi Ternate bolted from Tuna fish. As a complement of the food, they can also enjoy the Colo-colo sauce. Furthermore, Lapola Rice is the most famous food in this area. As for souvenirs, they buy Komu Asap fish or Sagu Komo Komo. For travelers who like seafood, Gatang Kemnari is a food that they should enjoy. The other heavy food is Jaha's rice, which should be. As a dessert, they can enjoy Sago roasted Talam and Sibu-sibu coffee.

\subsection{Infrastructure Development}


Accommodation and transportation are important in infrastructure development. Surrounding this beached there is only one resort named Ora Beach Resort. The resort has six cottages made of wood and a thatch roof. The location of this Resort is also secluded and away from the hustle and bustle of urban areas, perfect for those who like quietness. At night, ecotourists can hear the waves and enjoy the beautiful sky decorated with stars too. As morning comes of course, they had greeted by a stunning beach atmosphere, clear seawater and fresh morning air. (Sahetapy, 2015)

Moreover, ecotourists used a transportation to this beach from Patimura Ambon airport. Firstly, they went to port Tulehu. They used a public transport or taxi with travel time for an hour. Upon arrival at the harbor, they continued their journey to the port of Amahi by speedboats. The travel time it takes to get to this port is about 2 hours. After that, they continue the journey to the village of Sawai by using public transportation for 2 hours. Then, it takes 10 minutes to cross by motor boats from the village of Sawai to the beach. Alternatively, travelers can use other alternatives to the beach by renting a car from Patimura airport directly to Sawai village by traveling through Seram District and Central Maluku District. This trip is quite far and takes about one day and one night.

\subsection{Cultural Activities}

The development of cultural tourism destinations on this beach is still not well developed. This is due to the object of cultural tourism attraction has not been cultural tourism Bamboo Gila, tourist at broom, Cakalele dance tours, dance tours Sau Reka-reka, and dance Lenso.

\section{Discussion}

\subsection{Prospective Performance}

The results of the tabulation of respondents - stakeholders indicate the expected increase in CE performance on the beach of Ora (Table 2) in the future. There is a shift of interest in stakeholders. The first priority to ecotourists does not change, ie stay on travel, accommodation, and coastal resources' care. Subsequently, a priority shift of the ecotourists' interests in preserving of socio-economics became the management and sales of culinary ecotourism. In addition, their third priority is also from marine biota protection against infrastructure development. Furthermore, there is a change in the order of future performance expectations after the infrastructure development then noticed Cultural activities. Furthermore, after the development of cultural activities has been made, the choice of stakeholders in the future is more to the preserved of socio-economics. 
Table 2. Prospective performance of Ora coastal ecotourism

\begin{tabular}{|l|r|c|}
\hline Prospective performance of coastal ecotourism & Value & \% Freq \\
\hline Travel, accommodation, and coastal resources' care & 37 & 0,1796 \\
\hline Cultural activities & 33 & 0,1602 \\
\hline Preserved of socio-economics & 31 & 0,1505 \\
\hline Infrastructure development & 35 & 0,1699 \\
\hline Marine - biota protection & 34 & 0,1650 \\
\hline Management and sales of culinary ecotourism & 36 & 0,1748 \\
\hline Kappa Coefficient $=\mathbf{K}_{\mathbf{2}} \mathbf{0 , 7 6 3 0}$ & 0,7630 & \\
\hline
\end{tabular}

\subsection{Travel, Accommodation, and Coastal Resources’ Care}

In developing CE industry in this area is not easy. While, the development of tourism requires a process. This is due to many areas of development in it. So that, it requires a cross-sector planning form. The CE development-planning model is comprehensive and integrated. Some of the main issues that often face the arrangement of the area, still often seen less follow the technical rules of spatial arrangement.

For example, utilizing areas that have slope slopes is not feasible to be developed but still built into tourism objects, such as the construction of accommodation facilities, which can cause negative impact on the effort Ecotourism itself. For example, ineffective control over the construction of ecotourism facilities that penetrate protected areas. It could be one of the causes of erosion and flooding. Another problem of the ecotourism development activity is still focusing only on the development of physical aspects, such as just developing because of its natural potential such as the beach (Banya, 2015).

\subsection{Management and Sales of Culinary Ecotourism}

Managing and distributing over culinary ecotourism could be enhancing by communicating and distributing traditional food of the region through electronic and print media. Around this beach, many traditional foods could be a culinary ecotourism attraction. The ingredients in making such food obtained from coastal produce. The typical several foods on this beach are:

a. Papeda, this food made from sago flour choice that already tasted soured. Usually this food served as Tagas and yellow broth. Types of fish that become the basic ingredients of this food come from the form of fish Tongkol, Mubara, and Kakap red. One of the lunchtime traditions on Friday is to eat Papeda. It called Papeda sago and cooked with water. Its shape is similar to kanji glue. It generally eates with Soru sauce, which cooked for Soru sauce. It usually the Asar fish smoked with coconut husks. Soru means acid. The sauce is clear, with a tamarind-spicy tone, as well as the smokey aroma of the fish Asar. It feels impressive. 
b. The yellow nutmeg of Banda is a typical food of the region that served as a companion Papeda. The texture of this food is almost the same as the yellow fish soup. It is rich in flavor of nutmeg plus the sour taste of tomatoes and oranges.

c. Tagas-tagas is a companion food in the form of dried vegetables. It is almost similar to roast beans mixed with cassava leaves, papaya leaves, and papaya flowers. It chopped fine and fried dry. The locals are experts on processing this meal, so the bitter taste of the papaya leaf is hardly noticeable. This dry vegetable texture is very soft.

d. Gogu or Shasimi Ternate fish made from small pieces of tuna. The fish mixed with lemon, salt, basil, peanuts and some other stir-fry spices. This fish served almost half-cooked, as the concept of this foot should be enjoy in raw conditions. So that, the fish protein is maintained.

e. Colo-colo is a typical sauce of this region made from young tomato pieces, onion, and cayenne. All materials are thinly sliced and sprinkled with salt and limejuice. Then, this sauce added soy sauce and a bit of cooking oil used by frying fish once.

f. Lapola made from Tolo beans, rice, grated coconut, and salt. Ingredients: $250 \mathrm{~g}$ of cleaned toasted beans then soaked overnight, $600 \mathrm{ml}$ of water, a torn pandanus leaf, $500 \mathrm{~g}$ of cleaned rice, a young coconut grain, and Salt sufficiently. To make it: boil the Tolo beans until soft and the liquid dries. Take off a boils water together with pandan's leaves. Enter the rice then cooked on a small boiled it as the liquid is absorbed. Combine rice dough with the beans-grated boiled coconut-salt mixed flat. Move it all in the cage and steam it. Finally, while the heat stir slowly and fanned it to make the rice become fluffier.

g. The tourists that visit the beach Ora really like to buy these Komu-smokes fish as their souvenir. Komo fish is a skipjack in fresh form. To cook it, split and smoked with small embers. This fumigation done by using bamboo, which used it as a clamp and handle. This smoked fish processed into sauce or mixed with colo-colo sauce.

h. Sago sweet potatos porridge is a meal that is very tasty porridge. How to make, sweet potatoes boiled and mixed with brown sugar. Then added sago that absorbs the sugar sauce. Thus, the texture of this sago porridge is a porridge that is not sauce. Sugar watered that blends of sago make texture more and thicker. Then given topping in the form of coconut milk and pandan leaves.

i. Gatang Kenari, to cook it begins by splitting the crab from its shell, wash it clean, cut to pieces and fry up. After that, all the spices smoothed. Saute onion with 3 tablespoons oiled, then enter the lemongrass and fry until fragrant. Add the orange leaves, sprinkles that had been mashed and curly peppers. It had smoothed. Enter the coconut milk, add the salt mix well, and then enter the sugar. Once thickened to enter the fried crab. Add the sliced leeks and walnuts. 
j. Sago Komo Komo Woku is one of the processed sago into a typical food area. This food made from sago, lemongrass ginger, garlic, chopped fish, onion, coconut milk, onion slices, salt, and local spices.

k. Sibu-sibu coffee is a kind of traditionally mashed robusta coffee and served together as small pieces of walnut.

1. Sago roasted Talam is a dessert similar to sponge cake made from sago, brown sugar, sugar, red beans, and walnuts. After mixing well, the dough baked.

\subsection{Infrastructure Development}

Transportation facilities in the area around the beach are still less than optimal. In fact, one of the fundamental factors of realizing superior tourism is the completeness of infrastructure. Judging from the regional characteristics of the islands, this sector should be taking seriously. The local government did not give priority to infrastructure development, especially road infrastructure-sea, telecommunication and information. Factually, there is a lack of its development of telecommunication infrastructure based on field research.

From the road infrastructure, it is quite good. There are many national roads that penetrate to the areas. The roads to the villages have been paving. As a result, land transportation modes such as travel, buses, public transportation, already smooth. Pelni Ship, Great Pioneers and Ferry has made the voyage to some important point.

\subsection{Marine - Biota Protection}

The beach is located on the edge of the Manusela National Park forest which has a wealth of biodiversity, such as tug (Bruguiera sexangula), Bakau (Rhizo acuminate), ketapang (Terminalia catappa), Meranti (Shorea selanica). For a while there is bird species such as Ternate mushroom (Lorius garrulous), Purple Nose Nuri / black head of Nuri (L. domicella), Coconut Seram (Cacatua moluccensis).

On the beach, it is easy to see a variety of fishes going back and forth between coral reefs. There are fish Kaisa, Losi, Samanda, Gaca, Sikuda, and blue cockatoo. There are also tattoo fish, Kaluna, anchovies, Kawalinya, pockets, skipjack, palapa, and grouper. According to the Deputy Governor of Maluku, this province is a major producer of fish. Of the approximately nine million tons of fish responses nationwide, 1.7 million tonnes are from Maluku. The famous fish is bubara, snapper, grouper, skipjack, Tuna and Sikuda.

\subsection{Cultural Activities}

Currently in the development of CE activities have not seen efforts of creating new tourism objects that are non-physical, such as by developing the potential of culture owned by local people. Ceremonies held in various villages, Sasi ceremony, Timba Laor, Arumbae race, Attractions at Manayapu (broom stick), Pattimura Day Ceremony and others. All these cultural attractions have the potential to be developing as cultural attractions and attractions. In fact, there are still many other tourism potentials that developed by relating to the cultural 
and artistic aspects of this region. Development of cultural tourism destinations on this beach is still not considering well. Ancient heritage tours, art centers, handicraft centers (Banya, 2015).

\subsection{Preserved of Socio-Economics}

Increasing the spirit of development in the Maluku Islands became an important agenda, especially from the ecotourism sector. From historical studies, Maluku is a big nation and has a long story that can be socializing. Maluku also comes with beautiful and rich nature, as well as a multicultural cultural system. All these sectors, promising an expensive bargaining power for the advancement of ecotourism on the coast. The need for socialization of this CE by holding a large event organizer national / international class. This is very profitable, both in terms of management of promotional strategies and promotional networks owned by the event organizer. Next, take advantage of the mainstream media as promotional partners that are able to reach the public widely. Utilization of internet as a means of promotion is very important. While, the world community will be easy to know about ecotourism in this area via the internet, for example with the development of CE website in Maluku a qualified and interesting. Invite actively social media users to promote ecotourism. However, including bloggers to review many sides with ecotourism will enhance the understanding and interest in ecotourists in the future (Fitriani, 2015).

\section{Conclusion}

Tabulation and discussion results state that the beach is ready to become a CE destination. This performance indicates that the beach is ready to contribute to meet the target of tourism ministers in the future. The advantages of the beach eco-tourism attribute of it became the ecotourists' decision to visit the area in travelling. The main point of their decisions dominated by the performance of the coast's scenic is well maintained and preserved. Secondly, eco-activities result of an economic contribution to the local community - social interaction exists on them and ecotourism. The third advantages are marine - biota protection as an attraction of marine ecotourism such as diving. Three advantages became the competitive advantage of the beach's performance.

Moreover, there are a few opportunities in enhancing their performance in terms of ecotourism. Managing - sales of culinary ecotourism could be other coastal food is their attraction. They like to taste and enjoy the typical food of the region of its ingredients of a fresh sea fish-savory taste. Besides, fishing, marine and cultural eco-tourism would be the diversification of coast attraction there.

However, infrastructure development needed to be to develop well. This is very important to increase a number ecotourists that have limited time to visit this coast.

\section{Limitation of Study}

Due to time and cost constraints, other studies could be make in terms of cultural, fishing, and marine ecotourism. 


\section{Acknowledgments}

The Author sincerely wishes to thank many anonymous reviewers and Editorial Boards who have helped provide positive feedback - full support until the study is published.

\section{References}

Almeyda, A. M., Broadbent, E. N., Wyman, M. S., \& Durham, W. H. (2010), Ecotourism impacts in the Nicoya Peninsula, Costa Rica. Int. J. Tourism Res., 12, 803-819. https://doi.org/10.1002/jtr.797

Attemene, P., \& Eguavoen, I. (2017). Coastal ecotourism in The Gambia: Effects of sustainability communication on environments and rural livelihoods (No. 154). ZEF Working Paper Series.

Ban, J., \& Ramsaran, R. R. (2016). An Exploratory Examination of Service Quality Attributes in the Ecotourism Industry, Journal of Travel \& Tourism Marketing, 34(1), 132-148. https://doi.org/10.1080/10548408.2016.1141155

Banya, D. (2015). Given the Challenges and Potential of Tourism Maluku, Kompasiana. Retrieved from http://www.kompasiana.com/shulhan/menilik-tag-and-potensi-pariwisata-maluku_5535bace6 ea834e22bda42d0

Bryman, A. (2006). Integrating quantitative and qualitative research: how is it done? Qualitative research, 6(1), 97-113. https://doi.org/10.1177/1468794106058877

Boley, B. B., \& Green, G. T. (2016). Ecotourism and natural resource conservation: the 'potential' for a sustainable symbiotic relationship, Journal of Ecotourism, 15(2), 122-138. https://doi.org/10.1080/14724049.2015.1094080

Buckley, R. (2009). Ecotourism: Principles and practices. CABI. 218-252

Chien, M. C. (2016). An empirical study on the effect of attractiveness of ecotourism destination on experiential value and revisit intention, Applied Ecology and Environmental Research, 15(2), 43-53. https://doi.org/10.15666/aeer/1502_043053

Conway, T., \& Cawley, M. (2016). Defining ecotourism: evidence of provider perspectives from an emerging area, Journal of Ecotourism, 15(2), 122-138. https://doi.org/10.1080/14724049.2016.1153105

Chris (2015 Chris (2015). Development of tourism destination in Maluku. Merdeka Village. Retrieved from http://desamerdeka.id/pengembangan-destinasi-wisata-di-maluku/

Cobbinah, P. B. (2015). Contextualising the meaning of ecotourism, Tourism Management Perspectives, 16, 179-189. https://doi.org/10.1016/j.tmp.2015.07.015

Diamantis, D. (2000), Ecotourism and sustainability in Mediterranean islands. Thunderbird Int'l Bus Rev, 42, 427-443. 
https://doi.org/10.1002/1520-6874(200007/08)42:4<427::AID-TIE5>3.0.CO;2-G

Fay (2017). 2020, Tourism Becomes Indonesia's Largest Foreign Exchange Donor, Pelatihanpariwisata.com. Retrieved from http://pelatihanpariwisata.com/2020-pariwisata-jadi-penyumbang-devisa-terbesar-indonesia/

Febryna, R. (2014). Ora Beach, the Indonesian Heaven of the World in Maluku. Coverage 6. Retrieved from http://news.liputan6.com/read/2060164/pantai-ora-surga-world-indonesia-yang-ada-di-maluk $\mathrm{u}$

Fitriani, E. (2015). Promosi Diprioritaskan ke 10 Destinasi Unggulan Wisata, Berita satu. Retrieved from http://www.beritasatu.com/food-travel/330485-promosi-diprioritaskan-ke-10-destinasi-unggu lan-wisata.html

Fitzgerald, L. A., \& Stronza, A. L. (2016). In Defense of the Ecotourism Shield: A Response to Geffroy et al., Trends in Ecology \& Evolution, 31(2), 94-95. https://doi.org/10.1016/j.tree.2015.11.002

Gottschalk, L. A. (2013). Content Analysis of Verbal Behavior: New Findings and Clinical Applications, Routledge, 19-22

Halim, H. S. (2011). Improving coastal tourism business competitiveness: Using ecotourism's concept to explore to potential of coastal tourism business Pandeglang and Serang Districts. Banten. West-Java. Indonesia. International Journal of Business and Social Science, 2(11). 87-90.

Halim, H. S. (2014). Excogitated Coastal Tourism Competitiveness by Implementing Eco-tourism in Anyer, Banten, Indonesia, International Journal of Marines Science, 4(7), 74-81. https://doi.org/10.5376/ijms.2014.04.0007

Henderson, K. (1991). Dimensions of Choice: A Qualitative Approach to Recreation, Parks, and Leisure Research. Venture. State College. Australia

Hengky, S. H. (2017a). Beholding Tanjung Pesona Coastal-ecotourism in Bangka Islands, Indonesia. Business and Economic Research, 7(2), 102-117. https://doi.org/10.5296/ber.v7i2.11552

Hengky, S. H. (2017b). Gazing Coastal Ecotourism in Morotai Islands, Indonesia. Environmental Management and Sustainable Development, 6(2), 144-157. https://doi.org/10.5296/emsd.v6i2.11393

Hengky, S. H. (2017c). Probing Coastal Eco-Tourism in Pasir Putih Beach, Indonesia. Business and Management Horizons, 5(1), 1-11. https://doi.org/10.5296/bmh.v5i1.10606

Hengky, S. H. (2017d). Scrutinizing Coastal Ecotourism in Gili Trawangan, Indonesia, International Journal of Marine Science, 7(25), 247-259. 
https://doi.org/10.5376/ijms.2017.07.0025

Honey, M. (2008). Ecotourism and Sustainable Development, Second Edition: Who Owns Paradise? Washington, D.C.: Island Press, 28-33

Kelkit, A., Celik, S., \& Eşbah, H. (2010). Ecotourism potential of Gallipoli Peninsula historical national park, Journal of Coastal Research, 26(3), 562-568. https://doi.org/10.2112/09-1181.1

Krause, A., \& Weir, E. (2011). Ecotourism: Management, Development and Impact, Nova Science Publishers. Hauppauge, New York

Lloret, J., \& Riera, V. (2008). Evolution of a Mediterranean Coastal Zone: Human Impacts on the Marine Environment of Cape Creus, Environmental Management, 42, 977-988. https://doi.org/10.1007/s00267-008-9196-1

Loperena, C. A. (2016). Honduras is open for business: extractivist tourism as sustainable development in the wake of disaster? Journal of Sustainable Tourism, 25(5), 618-633. https://doi.org/10.1080/09669582.2016.1231808

Marwick, D. P., \& Uniger, C. H. (1975). The Sample Survey, Theory and Practice, Mc Graw Hill Book Co, New York.

MC (2017). 2019 Tourism Indonesia Targeted Best In Asean, Malukuchannel.com. Retrieved from http://www.malukuchannel.com/2017/02/pariwisata-indonesia-ditargetkan.html

Nouri, J., Danehkar, A., \& Sharifipour, R. (2008). Evaluation of ecotourism potential in the northern coastline of the Persian Gulf, Environment Geology, 55(3), 681-686. https://doi.org/10.1007/s00254-007-1018-X

Nuzula, N. I., Armono, H. D., \& Rosyid, D. M. (2017). Management of Baluran National Park Resources for Coastal Ecotourism Based on Suitability and Carrying Capacity, Applied $\begin{array}{llll}\text { Mechanics } \quad \text { and } & \text { Materials, 862, }\end{array}$ https://doi.org/10.4028/www.scientific.net/AMM.862.161

Pace, N. L., \& Morgan, N. (2017). Living Shorelines: Eroding Regulatory Barriers to Coastal Resilience, Natural Resources \& Environment, 31(3), 44-47

Patty, R. R. (2015). Lack of Budget Affect Tourism Promotion of Maluku, KOmpas.com. Retrieved from http://travel.kompas.com/read/2015/02/28/143900327/Minimnya.Anggaran.Pengaruhi.Promo si.Pariwisata.Maluku.

Picard, D. (2015). Making ecotourism sustainable: refocusing on economic viability. Lessons learnt from the "Regional strategic action plan for coastal ecotourism development in the South Western Indian Ocean”, Journal of Sustainable Tourism, 23(6), 819-837. https://doi.org/10.1080/09669582.2015.1019512 
Porter, B. A., Orams, M. B., \& Lück, M. (2015). Surf-riding tourism in coastal fishing communities: A comparative case study of two projects from the Philippines, Ocean \& Coastal Management, 116, 169-176. https://doi.org/10.1016/j.ocecoaman.2015.07.015

Riani, A. (2015). Escape to Paradise Coral Coast Ora, Bintang. Retrieved from http://www.bintang.com/food-travel/read/2265128/melarikan-diri-ke-surga-koral-pantai-ora

Rusli, Santosa, H. R., \& Soemarno, I. (2015). Coastal ecotourism-based development for fishermen settlement in Labuan Bajo, Donggala, Central Sulawesi, International Journal of Development Research, 5(08), 5215-5221

Sakata, H., \& Prideaux, B. (2013). An alternative approach to community-based ecotourism: a bottom-up locally initiated non-monetised project in Papua New Guinea, Journal of Sustainable Tourism, 21, 880-899. https://doi.org/10.1080/09669582.2012.756493

Sahetapy, C. (2015). Development of tourism destination in maluku, Retrieved from http://desamerdeka.id/development-destinasi-wisata-di-maluku/

Surya, M. A. (2015a). Waves, Hymns, and Stories about Crabs Entering Rooms, Seconds News. Retrieved from https://news.detik.com/berita/d-3050589/ombak-nyanyian-malam-dan-cerita-abentang-kepiti ng-yang-asuk-room

Surya, M. A. (2015b). Watch out! Kaking the Killer, Seconds news. Retrieved from https://news.detik.com/berita/d-3052326/awas-kaking-sang- killer

\section{Copyright Disclaimer}

Copyright for this article is retained by the author(s), with first publication rights granted to the journal.

This is an open-access article distributed under the terms and conditions of the Creative Commons Attribution license (http://creativecommons.org/licenses/by/4.0/). 